\title{
PENGARUH MODAL INTELEKTUAL, BIAYA PROMOSI, DAN PERPUTARAN PERSEDIAAN DALAM MEMPENGARUHI PROFIT SERTA IMPLIKASINYA TERHADAP NILAI PERUSAHAAN
}

\author{
Oleh: \\ Susanti Widhiastuti'1), R. Rama Satrya Nugraha') \\ santiwidhiastuti@gmail.com ${ }^{1)}$, insightpower@ymail.com ${ }^{2}$ \\ Sekolah Tinggi Ilmu Ekonomi IPWI Jakarta
}

\begin{abstract}
ABSTRAK
Penelitian ini bertujuan untuk menganalisis pengaruh modal intelektual (IC), biaya promosi, dan perputaran persediaan (ITO) terhadap profit (ROA) serta implikasinya terhadap nilai perusahaan (PER). Populasi pada penelitian ini adalah perusahaan pada Sektor Industri Manufaktur Barang Konsumsi yang terdaftar di Bursa Efek Indonesia periode tahun 2012 sampai dengan tahun 2016 dengan jumlah 42 perusahaan. Pemilihan sampel dilakukan dengan menggunakan metode purposive sampling dan sampel yang digunakan dalam penelitian ini berjumlah 18 perusahaan. Jenis penelitian yang digunakan dalam penelitian ini adalah explanatory research tipe kausal yang berupaya menguji pengaruh antar variabel dalam sebuah model struktural.

Hasil penelitian menunjukkan bahwa modal intelektual berpengaruh terhadap profit perusahaan tetapi tidak berpengaruh terhadap nilai perusahaan. Biaya promosi tidak berpengaruh terhadap profit dan nilai perusahaan. Perputaran persediaan tidak berpengaruh terhadap profit tetapi berpengaruh terhadap nilai perusahaan.
\end{abstract}

Kata Kunci: Modal Intelektual, Biaya Promosi, Perputaran Persediaan, Profit, Nilai Perusahaan

\section{PENDAHULUAN}

Tingkat persaingan yang ketat pada perusahaan khususnya perusahaan industri manufaktur, telah mengubah perusahaan untuk menjalankan bisnisnya dari bisnis yang didasarkan pada tenaga kerja menuju bisnis berdasarkan pengetahuan atau dengan memaksimalkan modal intelektual yang dimiliki perusahaan berupa modal sumber daya manusia, modal struktural dan modal relasi dan didukung juga oleh biaya promosi dengan harapan dapat meningkatkan profit perusahaan yang dalam penelitian ini diukur dengan Return on Asset (ROA) dan berdampak pula pada peningkatan nilai perusahaan yang diukur dengan Price Earning Ratio (PER). Nilai perusahaan didukung juga oleh tingkat perputaran persediaan (Inventory Turn Over (ITO)). Nilai perusahaan pada penelitian ini diukur menggunakan Price Earning Ratio (PER) karena gambaran nilai earning dari nilai saham di masa depan merupakan dasar utama pengambilan keputusan dari pemegang saham untuk membeli, mempertahankan, atau melepas sahamnya.

Profitabilitas memiliki peranan yang penting untuk penilaian kinerja perusahaan, terutama dalam perspektif operasional dan manajemen organisasi. Irawati (2006) menyebutkan bahwa rasio dari profitabilitas digunakan untuk mengukur efisiensi penggunaan aktiva perusahaan dan kemampuan perusahaan dalam beroperasi secara efisien. Profitabilitas dipilih sebagai variabel intervening dari nilai perusahaan karena modal intelektual, biaya promosi, dan perputaran persediaan dapat mempengaruhi profit di samping berpengaruh juga terhadap nilai perusahaan. Selain profit terdapat variabel lain yaitu biaya promosi. Biaya 
promosi sangat penting untuk meningkatkan profit perusahaan, betapapun berkualitasnya suatu produk, jika konsumen belum pernah mendengarkan dan tidak yakin bahwa produk itu akan berguna bagi mereka, maka mereka tidak akan membelinya. Promosi tidak hanya untuk menarik minat konsumen, tetapi juga merupakan bentuk komunikasi perusahaan dengan konsumen dan pelanggannya.

Berdasarkan data empiris tentang pengaruh modal intelektual, biaya promosi, dan perputaran persediaan dalam mempengaruhi profit serta implikasinya terhadap nilai perusahaan pada perusahaan industri manufaktur barang konsumsi, mendorong dilakukannya penelitian di samping saran dari penelitian sebelumnya yang membahas tentang variabel intelektual (Fauzi, 2016 dan Zulfiani, 2016), biaya promosi (Rahmanita, 2017), perputaran persediaan (Fahmi, 2012), nilai perusahaan (Asteria, 2016), dan gap penelitian. Gap tersebut di antarnya dari penelitian Wijaya dan Tjun (2017) yang menyebutkan bahwa ITO berpengaruh signifikan dan positif terhadap Return on Asset. Penelitian ini didukung oleh Kridasusila dan Rachmawati (2016) dan Fadilah et al (2017). Tetapi tidak didukung dalam penelitian Iskarisma (2017) menyebutkan bahwa ITO tidak berpengaruh terhadap Return on Asset.

\section{TUJUAN PENELITIAN}

Penelitian ini bertujuan untuk menganalisis pengaruh modal intelektual, biaya promosi, dan perputaran persediaan dalam mempengaruhi profit serta implikasinya terhadap nilai perusahaan.

\section{TELAAH LITERATUR DAN PENGEMBANGAN

Modal intelektual merupakan asset dan sumber daya tidak berwujud dari sebuah organisasi, yaitu mencakup proses, kapasitas inovasi, pola-pola, dan pengetahuan yang tidak kelihatan dari para anggotanya dan jaringan koloborasi serta hubungan organisasi.
Komponen utama yang diungkapkan dalam intellectual adalah human capital, structural capital, dan relational capital (Zurnali, 2010). Modal intelektual merupakan aktiva tidak berwujud yang ada di dalam perusahaan dan kemampuannya dalam menciptakan nilai tambah dari biaya yang dikeluarkan. Sumber dari aktiva tidak berwujud dari perusahaan ini adalah modal manusia, struktural, dan pelanggan (Ikhsan, 2008).

\section{Biaya Promosi}

Kotler dan Keller (2006:23) menjelaskan bahwa bauran pemasaran atau promosi harus dibuat untuk memengaruhi bauran tawaran produk, jasa, dan harga serta memanfaatkan satu bauran komunikasi dari iklan, promosi penjualan, acara khusus dan pengalaman, hubungan masyarakat, pemasaran langsung, dan penjualan pribadi. Indikator biaya promosi yang digunakan dalam penelitian ini berupa gabungan antar biaya iklan ditambah biaya promosi penjualan.

American Marketing Association (2015) menyebutkan bahwa kegiatan pemasaran merupakan aktivitas, kebiasaan, dan proses untuk menciptakan, berkomunikasi, memberikan, dan bertukar penawaran yang memiliki nilai bagi pelanggan, klien, mitra kerja, dan masyarakat pada umumnya.

\section{Perputaran Persediaan}

Perputaran persediaan merupakan rasio yang digunakan untuk mengukur berapa kali dana yang ditanam dalam persediaan (inventory) berputar dalam satu periode. Rasio ini dikenal dengan nama rasio perputaran persediaan (inventory turn over). Perputaran persediaan merupakan rasio yang menunjukkan berapa kali jumlah barang persediaan diganti dalam satu tahun. Semakin kecil rasio ini berarti semakin jelek penilaiannya dan begitu pula sebaliknya (Kasmir, 2016).

\section{Profit}

Profit yang diukur dengan Return on Asset (ROA) adalah rasio untuk 
melihat sejauh mana investasi yang sudah ditanamkan mampu memberikan pengembalian keuntungan sesuai dengan yang diharapkan (Fahmi, 2012). Return on Asset juga menunjukkan kemampuan modal yang diinvestasikan dalam total aktiva untuk menghasilkan laba perusahaan. Semakin tinggi Return on Asset (ROA), maka kemungkinan pembagian dividen juga akan semakin besar (Sartono, 2010).

\section{Nilai Perusahaan}

Nilai perusahaan yang diukur dengan Price Earning Ratio (PER). PER menunjukkan rasio dari harga saham terhadap earning (Jogiyanto, 2010). Price Earning Ratio dapat digunakan sebagai metode analisis fundamental dalam penilaian kinerja saham. Pendekatan ini digunakan untuk memperkirakan nilai saham dengan cara membagi harga saham saat ini dengan Earning Per Share dari saham tersebut. Pendekatan ini tidak memperhatikan nilai waktu uang (Jones, 2000).

\section{Hipotesis \\ H1 : Modal Intelektual Berpengaruh terhadap Profit Perusahaan}

Intellectual capital merupakan aktiva tidak berwujud yang dimiliki perusahaan dan dapat menciptakan profit yang berdampak pada peningkatan nilai perusahaan. Nilai tambah merupakan ukuran yang merefleksikan kontribusi karyawan dan manajemen pada penciptaan nilai. Semakin tinggi nilai tambah berarti memastikan semakin tingginya dividen bagi pemegang saham, pajak, dan meningkatnya investasi untuk pengembangan perusahaan disebabkan profitabilitas meningkat (Pulic, 2008).

Penelitian yang dilakukan oleh Agustina dkk (2015) dan Bentoen (2012) menjelaskan tentang pengaruh modal intelektual terhadap profit perusahaan. Penelitian menghasilkan temuan bahwa modal intelektual berpengaruh terhadap profit perusahaan. Penelitian lain dilakukan oleh Bentoen (2012) menghasilkan temuan bahwa modal intelektual juga berpengaruh terhadap profit perusahaan.

\section{H2 : Biaya Promosi (BPR) Berpengaruh terhadap Profit Perusahaan}

Kegiatan pemasaran merupakan aktivitas, kebiasaan, dan proses untuk menciptakan dan berkomunikasi dan bertukar penawaran bagi pelanggan, klien, mitra kerja, dan masyarakat pada umumnya. Rahmanita (2017) melakukan penelitian mengenai pengaruh biaya promosi terhadap profit perusahaan dan hasil penelitian menunjukkan bahwa biaya promosi berpengaruh profit perusahaan.

\section{H3 : Perputaran Persediaan (ITO) Berpengaruh terhadap Profit Perusahaan (ROA)}

Perputaran persediaan merupakan rasio yang digunakan untuk mengukur berapa kali dana yang ditanam dalam persediaan berputar dalam satu periode. Semakin kecil rasio ini berarti semakin menurun niali persediaannya dan sebaliknya (Kasmir, 2016). Penelitian mengenai pengaruh perputaran persediaan terhadap profit perusahaan dilakukan oleh Wijaya dan Tjun (2017). Hasil penelitian menunjukkan bahwa perputaran persediaan berpengaruh terhadap profit perusahaan. Penelitian ini juga didukung oleh penelitian Kridasusila dan Rachmawati (2016), Hartini (2017), dan Fadilah et al (2017).

\section{H4 : Modal Intelektual (IC) Berpengaruh terhadap Nilai Perusahaan}

Modal intelektual memiliki peran penting untuk meningkatkan nilai perusahaan. Zulfiani (2016) melakukan penelitian mengenai pengaruh modal intelektual terhadap nilai perusahaan. Penelitian menghasilkan temuan bahwa modal intelektual berpengaruh terhadap price earning ratio sebagai ukuran nilai perusahaan. Hasil ini pun didukung oleh penelitian Yans (2012) dan Bentoen (2012).

\begin{tabular}{lll} 
H5 : Biaya & \multicolumn{1}{c}{$\begin{array}{c}\text { Promosi } \\
\text { Berpengaruh }\end{array}$} & $\begin{array}{l}\text { (BPR) } \\
\text { terhadap }\end{array}$ \\
$\begin{array}{l}\text { Nilai } \\
\text { Perusahaan }\end{array}$ & & \\
Penelitian & yang & dilakukan \\
Rahmanita (2017) & tentang & pengaruh
\end{tabular}


biaya promosi terhadap laba bersih menghasilkan temuan bahwa biaya promosi berpengaruh terhadap profit perusahaan. Dengan profit yang diperoleh perusahaan diharapkan dapat meningkatkan nilai perusahaannya yang tercermin dari harga saham yang dimiliki.

\section{H6 : Perputaran Persediaan (ITO) Berpengaruh terhadap Nilai Perusahaan (PER)}

Sitepu dan Linda (2013) melakukan penelitian mengenai pengaruh perputaran persediaan terhadap nilai perusahaan. Penelitian menghasilkan temuan bahwa perputaran persediaan berpengaruh terhadap nilai perusahaan. Penelitian ini pun didukung oleh Purwani (2013) dan Surpiyadi (2015).

\section{H7 : Profit (ROA) Berpengaruh terhadap Nilai Perusahaan (PER)}

Laba yang diperoleh perusahaan dapat meningkatkan nilai perusahaan. Dengan laba yang dimiliki memungkinkan perusahaan untuk lebih leluasa meningkatkan nilai perusahaan. Penelitian Mandasari (2016) tentang profit perusahaan terhadap nilai perusahaan menghasilkan bahwa profit berpengaruh terhadap nilai perusahaan. Penelitian ini didukung oleh penelitian dari Asteria (2016) dan Danial (2014).

\section{Gambar 1}

Kerangka/Konstelasi

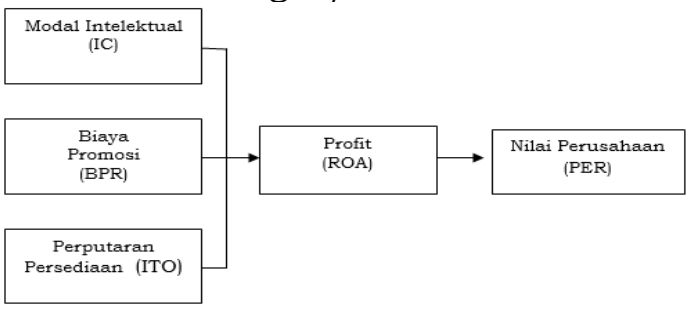

\section{METODE PENELITIAN}

Jenis data yang digunakan dalam penelitian ini berupa data sekunder yaitu laporan keuangan tahunan Industri Manufaktur Barang Konsumsi yang terdaftar dalam Bursa Efek Indonesia selama periode 2012 - 2016. Sumber data yang dikumpulkan langsung berasal dari laman resmi BEI melalui www.idx.co.id.
Penelitian ini terdiri dari tiga variabel independen atau variabel bebas (X) yaitu modal intelektual (IC), biaya promosi (BPR), dan perputaran persediaan (ITO), dua variabel dependen atau variabel terikat yang terdiri dari satu variabel intervening yaitu profit (ROA) dengan menggunakan simbol (Z) dan satu variabel dependen yaitu nilai perusahaan (PER) dengan simbol (Y).

\section{Sampel Penelitian}

Populasi pada penelitian ini adalah konsumen perusahaan-perusahaan yang termasuk dalam Sektor Industri Manufaktur Barang Konsumsi yang terdaftar di Bursa Efek Indonesia periode tahun 2012 - 2016 dengan jumlah 42 perusahaan. Pemilihan sampel dilakukan dengan menggunakan metode purposive sampling yaitu:

a. Perusahaan yang konsisten menerbitkan laporan tahunan selama periode 2012 - 2016;

b. Membukukan laba bersih positif;

c. Melengkapi laporan tahunannya dengan Financial Statement.

Sampel yang digunakan dalam penelitian ini berjumlah 18 perusahaan dari 42 perusahaan yang tercatat dalam Sektor Industri Manufaktur Barang Konsumsi.

\section{Operasionalisasi Variabe1}

Tabel 1

Operasionalisasi Variabel

\begin{tabular}{|l|c|}
\hline \multicolumn{1}{|c|}{ Variabel } & Rumus \\
\hline Modal Intelektual & VAIC $=$ HCE + SCE + CEE \\
\hline Biaya Promosi & BPR $=\frac{\text { Biaya Promosi }}{\text { Biaya Operasional }}$ \\
\hline Inventory Turn Over & ITO $=\frac{\text { Harga Pokok Penjualan }}{\text { Rata }- \text { rata Persediaan }}$ \\
\hline Return on Asset & ROA $=\frac{\text { Earning After Tax }}{\text { Total Asset }}$ \\
\hline Price Earning Ratio & PER $=\frac{\text { Market per Share }}{\text { Earning per Share }}$ \\
\hline
\end{tabular}

\section{Metode Analisis}

Metode analisis yang digunakan adalah analisis statistik deskriptif dan analisis regresi linear berganda yang terdiri dari uji asumsi klasik (normalitas, multikolinearitas, heteroskedastisitas, dan autokorelasi), uji model (koefisien determinasi R2, uji statistik F, dan uji t), 
dan uji variabel intervening (Sobel Test, 1982).

\section{HASIL DAN PEMBAHASAN Uji Asumsi Klasik}

Berdasarkan hasil uji normalitas, semua titik menyebar di sekitar dan mendekati garis diagonal. Ini menunjukkan bahwa data penelitian menunjukkan distribusi data normal. Hasil uji multikolinearitas pada variabel independen diperoleh nilai tolerance pada variabel penelitian di atas 0,1 dan nilai VIF di bawah 10 sehingga dapat dikatakan tidak terjadi korelasi antar variabel bebas.

Uji heterokedastisitas terlihat titiktitik menyebar tanpa membentuk pola tertentu dan menyebar di atas dan di bawah angka 0 pada sumbu Y. Dengan demikian data-data pada penelitian ini tidak terjadi heteroskedastisitas. Untuk uji autokorelasi dari nilai dw sebesar 2,707 terletak antara 2,35 < dw $<2,79$ sehingga autokorelasi tidak dapat disimpulkan.

\section{Uji Model}

Model persamaan regresi linear dalam penelitian ini dirumuskan dalam persamaan sebagai berikut:

$\mathrm{ROA}=a+\beta 1 \mathrm{VAIC}+\beta 2 \mathrm{BPR}+\beta 3$ ITO

$\mathrm{PER}=a+\beta 4$ VAIC $+\beta 5 \mathrm{BPR}+\beta 6 \mathrm{ITO}+$ $\beta 7 \mathrm{ROA}$

\section{Uji Model pertama}

Uji model pertama adalah uji terhadap pengaruh Intellectual Capital (VAIC), Biaya Promosi (BPR), dan Inventory Turn Over (ITO) terhadap Return on Asset (ROA).

Tabel 2

Uji Adjusted R ${ }^{2}$ VAIC, BPR, ITO terhadap ROA

Model Summary

\begin{tabular}{l|r|r|r|r|}
\hline Model & $\mathrm{R}$ & R Square & $\begin{array}{c}\text { Adjusted R } \\
\text { Square }\end{array}$ & $\begin{array}{c}\text { Std. Error of } \\
\text { the Estimate }\end{array}$ \\
\hline 1 & $.708^{\mathrm{a}}$ & .501 & .483 & .07371 \\
\hline
\end{tabular}
a. Predictors: (Constant), ITO, VAIC, BPR
b. Dependent Variable: ROA

Sumber: Pengolahan Data Sekunder (2018)

Dari tabel di atas diperoleh diperoleh koefisien determinasi ganda Adjusted R2 $=0,483$. Ini menyatakan bahwa variabel independen (VAIC, BPR,
ITO) berpengaruh sebesar 48,3\% terhadap variabel dependen (ROA).

$$
\text { Tabel } 3
$$

Uji Sig F VAIC, BPR, ITO terhadap ROA

\begin{tabular}{|c|c|c|c|c|c|c|}
\hline \multicolumn{7}{|c|}{ ANOVA $^{a}$} \\
\hline & & $\begin{array}{c}\text { Sum of } \\
\text { Squares }\end{array}$ & df & $\begin{array}{c}\text { Mean } \\
\text { Square }\end{array}$ & $\mathrm{F}$ & Sig. \\
\hline \multirow{3}{*}{\begin{tabular}{|l}
1 \\
\end{tabular}} & Regression & .442 & 3 & \multirow{3}{*}{$\begin{array}{l}.147 \\
.005\end{array}$} & \multirow[t]{3}{*}{27.150} & \multirow[t]{3}{*}{.000} \\
\hline & Residual & .440 & 81 & & & \\
\hline & Total & .883 & 84 & & & \\
\hline
\end{tabular}

a. Dependent Variable: ROA

b. Predictors: (Constant), ITO, VAIC, BPR

Sumber: Pengolahan Data Sekunder (2018)

Dari tabel di atas didapatkan nilai Sig $F=0,000$. Ini menunjukkan bahwa $F$ hitung lebih kecil daripada taraf uji penelitian (Sig $\mathrm{F}<$ 0,005). Ini membuktikan bahwa Ho ditolak dan $\mathrm{Ha}$ diterima sehingga terdapat pengaruh yang signifikan dari variabel independen (VAIC, BPR, ITO) secara simultan terhadap variabel dependen (ROA). Tabel 4

Uji Model VAIC, BPR, ITO terhadap ROA

\begin{tabular}{|c|c|c|c|c|c|c|}
\hline \multicolumn{7}{|c|}{ Coefficients ${ }^{\mathrm{a}}$} \\
\hline \multirow[b]{2}{*}{ Model } & & \multicolumn{2}{|c|}{$\begin{array}{c}\text { Unstandardized } \\
\text { Coefficients }\end{array}$} & \multirow{2}{*}{$\begin{array}{c}\begin{array}{c}\text { Standardized } \\
\text { Coefficients }\end{array} \\
\text { Beta }\end{array}$} & \multirow[b]{2}{*}{$\mathrm{t}$} & \multirow[b]{2}{*}{ Sig. } \\
\hline & & B & $\begin{array}{l}\text { Std. } \\
\text { Error }\end{array}$ & & & \\
\hline 1 & $\begin{array}{l}\text { (Constant) } \\
\text { VAIC }\end{array}$ & \begin{tabular}{r|}
.019 \\
.039
\end{tabular} & $\begin{array}{l}.027 \\
.005\end{array}$ & .699 & \begin{tabular}{|l|}
-.709 \\
8.668
\end{tabular} & $\begin{array}{l}.480 \\
.000\end{array}$ \\
\hline & BPR & .049 & .060 & .066 & .821 & .414 \\
\hline & ITO & -.003 & .004 & -.060 & -.743 & .459 \\
\hline
\end{tabular}

Sumber: Pengolahan Data Sekunder (2018)

Berdasarkan tabel di atas maka didapatkan persamaan:

$\mathrm{ROA}=-0,19+0,039 \mathrm{VAIC}+0.049 \mathrm{BPR}$ $-0,003$ ITO

\section{Uji Model ke 2}

Uji model kedua adalah uji terhadap pengaruh Intellectual Capital (VAIC), Biaya Promosi (BPR), Inventory Turn Over (ITO), Return on Asset (ROA) terhadap Price Earning Ratio (PER).

Tabel 5

Uji Adjusted R² VAIC, BPR, ITO, ROA terhadap PER Model Summaryb

\begin{tabular}{l|r|r|r|r|}
\hline Model & $\mathrm{R}$ & R Square & $\begin{array}{c}\text { Adjusted R } \\
\text { Square }\end{array}$ & $\begin{array}{c}\text { Std. Error of } \\
\text { the Estimate }\end{array}$ \\
\hline 1 & $.551^{\mathrm{a}}$ & .303 & .269 & 8.86292 \\
\hline
\end{tabular}
a. Predictors: (Constant), ROA, ITO, BPR, VAIC
b. Dependent Variable: PER

Sumber: Pengolahan Data Sekunder (2018)

Dari tabel di atas diperoleh koefisien determinasi ganda Adjusted R2 = 0,269. 
Ini menyatakan bahwa variabel independen (VAIC, BPR, ITO, ROA) berpengaruh sebesar 26,9 \% terhadap variabel dependen (PER).

Tabel 6

Uji Sig F VAIC, BPR, ITO, ROA terhadap



Sumber: Pengolahan Data Sekunder (2018)

Dari tabel di atas didapatkan nilai Sig $F=0,000$. Ini menunjukkan bahwa $F$ hitung lebih kecil daripada taraf uji penelitian (Sig $\mathrm{F}<$ 0,005). Ini membuktikan bahwa Ho ditolak dan $\mathrm{Ha}$ diterima sehingga terdapat pengaruh yang signifikan dari variabel independen (VAIC, BPR, ITO, ROA) secara simultan terhadap variabel dependen (PER). Tabel 7

Uji Model VAIC, BPR, ITO, ROA terhadap PER

\begin{tabular}{|c|c|c|c|c|c|c|}
\hline \multirow[b]{2}{*}{ Mode } & & \multicolumn{2}{|c|}{$\begin{array}{l}\text { Unstandardized } \\
\text { Coefficients }\end{array}$} & \multirow{2}{*}{\begin{tabular}{|c|}
$\begin{array}{c}\text { Standardized } \\
\text { Coefficients }\end{array}$ \\
Beta \\
\end{tabular}} & \multirow[b]{2}{*}{$\mathrm{t}$} & \multirow[b]{2}{*}{ Sig. } \\
\hline & & $\mathrm{B}$ & $\begin{array}{l}\text { Std. } \\
\text { Error } \\
\end{array}$ & & & \\
\hline \multirow[t]{4}{*}{1} & $\begin{array}{l}\text { (Constant) } \\
\text { VAIC }\end{array}$ & $\begin{array}{r}6.925 \\
.416\end{array}$ & $\begin{array}{r}3.266 \\
.757\end{array}$ & .073 & $\begin{array}{r}2.120 \\
.550\end{array}$ & $\begin{array}{l}.370 \\
.584\end{array}$ \\
\hline & BPR & 9.814 & 7.188 & .132 & 1.365 & .716 \\
\hline & ITO & 1.326 & .488 & .260 & 2.718 & .008 \\
\hline & ROA & 36.056 & 13.361 & .357. & 2.699 & .008 \\
\hline
\end{tabular}

Sumber: Pengolahan Data Sekunder (2018)

Berdasarkan tabel di atas maka didapatkan persamaan:

$\mathrm{PER}=6,925+0,416 \mathrm{VAIC}+9,814 \mathrm{BPR}$ $+1,326$ ITO + 36,056 ROA

\section{Uji Hipotesis}

H1 : Pengaruh Modal Intelektual terhadap Profit

Berdasarkan persamaan regresi linear profit $=-0,19+0,039$ VAIC + 0.049 BPR - 0,003 ITO + 0,719 maka didapatkan nilai koefisien regresi VAIC sebesar $\beta 1=0,039$ dengan nilai signifikansi probabilitas $\mathrm{t}$ hitung sebesar 0,000 . Karena $\beta 1 \neq 0$ dan probabilitas $t$ hitung lebih kecil daripada taraf uji penelitian (Sig $\mathrm{t}<\alpha$ atau $0.000<0.05$ ), maka H1o ditolak dan H1a diterima, artinya terdapat pengaruh yang signifikan dari VAIC terhadap profit.

\section{H2 : Pengaruh Biaya Promosi terhadap Profit}

Berdasarkan persamaan regresi linear profit $=-0,19+0,039$ VAIC + 0.049 BPR - 0,003 ITO + 0,719 maka didapatkan nilai koefisien regresi BPR sebesar $\beta 2=0,049$ dengan nilai signifikansi probabilitas $\mathrm{t}$ hitung sebesar 0,414 . Karena $\beta 2 \neq 0$ dan probabilitas $t$ hitung lebih besar daripada taraf uji penelitian (Sig $\mathrm{t}>\alpha$ atau $0.414>0.05$ ), maka $\mathrm{H} 2 \mathrm{o}$ diterima dan $\mathrm{H} 2 \mathrm{a}$ ditolak, artinya terdapat pengaruh yang tidak signifikan dari BPR terhadap profit.

\section{H3 : Pengaruh Perputaran Persediaan terhadap Profit}

Berdasarkan persamaan regresi linear profit $=-0,19+0,039$ VAIC + 0.049 BPR - 0,003 ITO + 0,719 maka didapatkan nilai koefisien regresi ITO sebesar $\beta 3=-0,003$ dengan nilai signifikansi probabilitas $\mathrm{t}$ hitung sebesar 0,459 . Karena $\beta 3 \neq 0$ dan probabilitas $t$ hitung lebih besar daripada taraf uji penelitian (Sig $\mathrm{t}>\alpha$ atau $0.459>0.05$ ), maka H3o diterima dan $\mathrm{H} 3 \mathrm{a}$ ditolak, artinya terdapat pengaruh yang tidak signifikan dari ITO terhadap profit.

\section{H4 : Pengaruh Modal Intelektual terhadap Nilai Perusahaan}

Berdasarkan persamaan regresi linear nilai perusahaan $=6,925+0,416$ $\mathrm{VAIC}+9,814 \mathrm{BPR}+1,326 \mathrm{ITO}+36,056$ $\mathrm{ROA}+0,855$ maka didapatkan nilai koefisien regresi VAIC sebesar $\beta 4=$ 0,416 dengan nilai signifikansi probabilitas $\mathrm{t}$ hitung sebesar 0,584. Karena $\beta 4 \neq 0$ dan probabilitas $t$ hitung lebih besar daripada taraf uji penelitian (Sig $\mathrm{t}>\alpha$ atau $0.584>0.05$ ), maka $\mathrm{H} 4 \mathrm{o}$ diterima dan $\mathrm{H} 4 \mathrm{a}$ ditolak, artinya terdapat pengaruh yang tidak signifikan dari VAIC terhadap nilai perusahaan.

\section{H5 : Pengaruh Biaya Promosi terhadap Nilai Perusahaan}

Berdasarkan persamaan regresi linear nilai perusahaan $=6,925+0,416$ $\mathrm{VAIC}+9,814 \mathrm{BPR}+1,326 \mathrm{ITO}+36,056$ $\mathrm{ROA}+0,855$ maka didapatkan nilai 
koefisien regresi BPR sebesar $\beta 5=9,814$ dengan nilai signifikansi probabilitas $t$ hitung sebesar 0,176 . Karena $\beta 5 \neq 0$ dan probabilitas $\mathrm{t}$ hitung lebih besar daripada taraf uji penelitian (Sig $\mathrm{t}>\alpha$ atau $0.176>0.05)$, maka H5o diterima dan H5a ditolak, artinya terdapat pengaruh yang tidak signifikan dari BPR terhadap nilai perusahaan.

\section{H6 : Pengaruh Perputaran Persediaan terhadap Nilai Perusahaan}

Berdasarkan persamaan regresi linear nilai perusahaan $=6,925+0,416$ $\mathrm{VAIC}+9,814 \mathrm{BPR}+1,326 \mathrm{ITO}+36,056$ $\mathrm{ROA}+0,855$ maka didapatkan nilai koefisien regresi ITO sebesar $\beta 6=1,326$ dengan nilai signifikansi probabilitas $t$ hitung sebesar 0,008. Karena $\beta 6 \neq 0$ dan probabilitas $t$ hitung lebih kecil daripada taraf uji penelitian (Sig $\mathrm{t}<\alpha$ atau $0.006<0.05)$, maka H6o ditolak dan H6a diterima, artinya terdapat pengaruh yang signifikan dari ITO terhadap PER.

\section{H7 : Pengaruh Profit terhadap Nilai Perusahaan}

Berdasarkan persamaan regresi linear nilai perusahaan $=6,925+0,416$ $\mathrm{VAIC}+9,814 \mathrm{BPR}+1,326 \mathrm{ITO}+36,056$ $\mathrm{ROA}+0,855$ maka didapatkan nilai koefisien regresi ROA sebesar $\beta 7=$ 36,056 dengan nilai signifikansi probabilitas $t$ hitung sebesar 0,008. Karena $\beta 7 \neq 0$ dan probabilitas $t$ hitung lebih kecil daripada taraf uji penelitian (Sig $\mathrm{t}<\alpha$ atau $0.008<0.05$ ), maka H7o ditolak dan $\mathrm{H7a}$ diterima, artinya terdapat pengaruh yang signifikan dari ROA terhadap PER.

\section{Pembahasan terhadap Profit}

\section{Pengaruh}

Berdasarkan hasil pengujian terdapat pengaruh positif dari modal intelektual terhadap profit. $\mathrm{Hal}$ ini sesuai dengan penelitian Agustina et al (2015) dan Fauzi (2016) tetapi bertentangan dengan penelitian Bentoen (2012), Amri dan Daud (2008). Berdasarkan konsep menjelaskan bahwa apabila perusahaan memiliki sumber daya manusia yang berkualitas dan dimanfaatkan semaksimal mungkin, didukung aset yang tersedia untuk memfasilitasi sumber daya manusia serta memiliki modal relasi yang cukup kuat akan meningkatkan pendapatan dan berdampak pada profit perusahaan.

\section{Pengaruh Biaya Promosi terhadap Profit}

Berdasarkan hasil pengujian terdapat pengaruh yang tidak signifikan dari biaya promosi terhadap profit. Hasil penelitian ini tidak sesuai dengan penelitian Rahmanita (2017) bahwa biaya promosi berpengaruh signifikan dan positif terhadap profitabilitas. Hasil ini juga tidak sesuai dengan penelitian Ongkowibowo dan Hatane (2015), Serenia dan Hatane (2015), Mariana dan Hatane (2015).

\section{Pengaruh Perputaran Persediaan terhadap Profit}

Berdasarkan hasil pengujian terdapat pengaruh yang tidak signifikan dari perputaran persediaan terhadap profit. Penelitian ini didukung oleh penelitian Iskarisma (2017) yang menyebutkan bahwa Inventory Turn Over tidak berpengaruh terhadap Return on Asset dan didukung oleh Sari dan Budiasih (2014), Hartini (2017), dan Fadilah et al (2017). Dalam penelitian lain dari Wijaya dan Tjun (2017) menyebutkan bahwa Inventory Turn Over berpengaruh positif terhadap Return on Asset dan didukung oleh Kridasusila dan Rachmawati (2016). Dalam konsep persediaan, menjelaskan bahwa semakin tersedianya persediaan untuk memenuhi pesanan dapat memperlancar proses produksi. Hal ini akan meningkatkan penjualan yang berdampak pada peningkatan profit.

\section{Pengaruh Modal Intelektual terhadap Nilai Perusahaan}

Berdasarkan hasil pengujian terdapat pengaruh yang tidak signifikan dari modal intelektual terhadap nilai perusahaan. Hasil penelitian ini tidak sesuai dengan penelitian Yans (2012), Bentoen (2012), dan Zulfiani (2016) yang menghasilkan temuan bahwa intellectual capital berpengaruh 
signifikan positif terhadap price earning ratio. Dalam konsep menyebutkan bahwa peningkatan modal intelektual yang dapat dilakukan melalui modal sumber daya manusia, modal struktural dan modal relasi secara bersama-sama dapat meningkatkan nilai perusahaan.

\section{Pengaruh Biaya Promosi terhadap Nilai Perusahaan}

Berdasarkan hasil pengujian terdapat pengaruh yang tidak signifikan dari biaya promosi terhadap nilai perusahaan. Hal ini bertentangan dengan penelitian sebelumnya tentang promosi (Hatane, 2015) yang membahas pengaruh marketing activity terhadap profitabilitas dan market value perusahaan retail dan produksi besar memiliki pengaruh terhadap profit perusahaan. Hal ini sesuai dengan konsep dalam biaya promosi.

\section{Pengaruh Perputaran Persediaan terhadap Nilai Perusahaan}

Berdasarkan hasil pengujian terdapat pengaruh dari perputaran persediaan terhadap nilai perusahaan. Hal ini sesuai dengan penelitian Sitepu dan Linda (2013) yang telah melakukan penelitian dan menghasilkan temuan bahwa Inventory Turn Over berpengaruh tidak signifikan terhadap Price Earning Ratio. Penelitian ini pun didukung oleh Purwani (2013), Putri dan Yunita (2013), Surpiyadi (2015), dan Adawiyah (2013).

\section{Pengaruh Profit terhadap Nilai Perusahaan \\ Berdasarkan hasil pengujian terdapat pengaruh positif dari profit terhadap nilai perusahaan. Penelitian ini didukung oleh penlitian Mandasari (2016) menyimpulkan bahwa Return On Asset (ROA) memiliki pengaruh signifikan dan positif terhadap Price Earning Ratio (PER). Hasil ini pun didukung oleh penelitian Danial (2014) dan Asteria (2016).}

\section{KESIMPULAN}

\section{Simpulan}

- Modal intelektual berpengaruh terhadap profit.
- Biaya promosi tidak berpengaruh terhadap profit.

- Perputaran persediaan tidak berpengaruh terhadap profit.

- Modal intelektual tidak berpengaruh terhadap nilai perusahaan.

- Biaya promosi tidak berpengaruh terhadap nilai perusahaan.

- Perputaran persediaan berpengaruh terhadap nilai perusahaan.

- Profit berpengaruh terhadap nilai perusahaan

\section{Saran}

- Bagi perusahaan, modal intelektual berpengaruh terhadap peningkatan profit perusahaan, hal ini menunjukkan bahwa perusahaan harus memperhatikan sumber daya manusianya sebagai modal yang tidak berwujud selain aset fisik yang dimiliki dan modal relasi walaupun tidak berpengaruh secara signifikan terhadap nilai perusahaan. Modal manusia dapat menciptakan inovasi dan kreasi produk. Perputaran persediaan sangat membantu perusahaan untuk kelancaran proses produksi dalam rangka memenuhi pesanan walaupun pengaruhnya tidak signifikan tetapi harus diperhatikan, demikian juga biaya promosi.

- Bagi peneliti selanjutnya adalah melakukan penelitian dengan menggunakan variabel independen lain yang mempengaruhi profit seperti modal kerja, leverage, dan menambah periode waktu.

\section{DAFTAR PUSTAKA}

Adawiyah, F. 2013. Analisis Pengaruh Current Ratio, DER, ITO dan ROA terhadap PER pada Perusahaan Consumer Goods yang terdapat di BEI Periode 2010 - 2012, Tangerang: Universitas Bina Nusantara.

Agustina, W., N. K. Sinarwati, dan G. A. Yuniarta. 2015. Pengaruh Intellectual Capital, Corporate Social Responsibility dan Good Corporate Governance terhadap Kinerja Keuangan. e-journal Jurnal Imiah Mahasiswa Akuntansi. 
Singaraja: Universitas Pendidikan Ganesha.

American Marketing Association. 2015. Definition of Marketing. Retrieved from American Marketing Association.

Amri, A dan R. M. Daud. 2008. Pengaruh Intellectual Capital dan Corporate Social Responsibility terhadap Kinerja Perusahaan. Jurnal Telaah Riset Akuntansi, Vol.1. Daerah Istimewa Aceh: Universitas Syiah Kuala.

Asteria, B. 2016. Analisis Faktor-Faktor yang Mempengaruhi Price Earning Ratio pada Perusahaan LQ 45, Jurnal Riset Manajemen, Vol.3. Yogyakarta: STIE Widya Wiwaha.

Bentoen, S. 2012, Pengaruh Intellectual Capital terhadap Financial Performance, Growth, dan Market Value. Surabaya: Program Study Akuntansi, Universitas Pelita Harapan.

Danial. 2014. Pengaruh ROA, DPR dan Size Perusahaan terhadap PER pada Perusahaan Aneka Industri dan Industri Barang Konsumsi di Bursa Efek Indonesia Tahun 2009 - 2012. Tanjungpinang: Universitas Maritim Raja Ali Haji.

Fadilah, N., E. Ghani, dan E. Amaniyah. 2017. Pengaruh Quick Ratio, Inventory Turn Over dan Debt to Equity Ratio terhadap Rentabilitas pada Perusahaan Kabel yang terdaftar di Bursa Efek Indonesia. Madura: Universitas Trunojoyo.

Fahmi, I. 2012. Analisis Laporan Keuangan, Cetakan 1. Bandung: Alfabeta.

Fauzi, Achmad. 2016. Analisis Pengaruh Intellectual Capital terhadap Nilai Perusahaan dengan Kinerja Keuangan sebagai Variabel Intervening. Jakarta: Program Studi Manajemen Universitas Islam Negeri Syarif Hidayatullah.

Hartini, Y. 2017. Pengaruh Current Ratio, Inventory Turn Over, dan Debt to Equity Ratio terhadap Return on Asset pada Perusahaan Manufaktur Tekstil dan Garment yang Terdaftar di Bursa Efek Indonesia Periode 2011 - 2016.
Batam: Akademi Akuntansi Permata Harapan.

Ikhsan, A. 2008. Akuntansi Sumber Daya Manusia. Edisi 1. Yogyakarta: Graha Ilmu,

Irawati, S. 2006. Manajemen Keuangan. Bandung: Pustaka.

Iskarisma, E, 2017. Pengaruh Current Ratio, Total Asset Turn Over, Inventory Turn Over, Debt to Equity Ratio, dan Umur Perusahaan terhadap Return on Asset pada Perusahaan Food and Beverage yang Terdaftar di BEI Periode $2011 \quad$ - 2015. Tanjungpinang: Universitas Maritim Raja Ali Haji.

Jogiyanto, H. 2010. Teori Portofolio dan Analisis Investasi, Edisi 7. Yogyakarta: BPFE.

Jones, C.P. 2000. Investment Analysis and Management, Edisi 7. New York: John Wiley and Sons Inc.

Kasmir. 2016. Analisis Laporan Keuangan. Jakarta: Rajawali Pers.

Kotler, P dan K. L. Keller. 2006. PrinsipPrinsip Pemasaran, Alih Bahasa Bob Sadran. Jakarta: Erlangga.

Kridasusila, A dan W. Rachmawati. 2016. Analisis Pengaruh Current Ratio, Inventory Turn Over, dan Debt to Equity Ratio pada Perusahaan Otomotif dan Produk Komponennya pada Bursa Efek Indonesia 2010 - 2013. Jurnal Dinamika Sosial dan Budaya, Vol. 18, No. 1.

Mandasari, P. 2016. Pengaruh DPR, DER, dan ROA terhadap PER pada Perusahaan Sektor Barang Konsumsi yang Terdaftar di BEI. Jurnal Profita, Edisi ke Tujuh, Yogyakarta: Program Study Akuntansi Fakultas Ekonomi Universitas Negeri Yogyakarta.

Mariana dan S. E. Hatane. 2015. Pengaruh Aktivitas Pemasaran terhadap Profitabilitas dan Nilai Perusahaan Perusahaan Makanan, Minuman, dan Rokok, Business Accounting Review, Vol. 3. Surabaya: Universitas Kristen Petra.

Ongkowibowo, D. T dan S. E. Hatane. 2015. Pengaruh Marketing Activity 
terhadap Profitabilitas dan Market Value Perusahaan Retail dan Produksi Besar. Business Accounting Reviewi Vol. 3. Surabaya: Universitas Kristen Petra.

Pulic, A. 2008. The Principles of Intellectual Capital Efficiency. Zargeb: Croatian Intellectual Capital Center.

Purwani, H. 2013. Pengaruh Current Ratio, Inventory Turn Over, Rasio Utang, dan Return on Equity terhadap Price Earning Ratio pada Perusahaan Makanan dan Minuman yang Terdaftar di Bursa Efek Indonesia periode 2009 2011. Yogyakarta: Universitas Negeri Yogyakarta.

Putri, M. F dan I. Yunita. 2013. Analisis Pengaruh Current Ratio, Debt to Equity Ratio, Inventory Turn Over, dan Return on Asset terhadap Price Earning Ratio pada Perusahaan Industri Otomotif yang Terdaftar di Bursa Efek Indonesia 2009 - 2013. Bandung: Universitas Telkom.

Rahmanita, M. 2017. Pengaruh Biaya Promosi dan Biaya Produksi terhadap Laba Bersih dengan Volume Penjualan sebagai Variabel Intervening. Surakarta: Fakultas Ekonomi dan Bisnis Islam Institut Agama Islam Negeri.

Sari, V dan I. G. A. N. Budiasih. 2014. Pengaruh Debt to Equity Ratio, Firm Size, Inventory Turn Over, dan Asset Turn Over terhadap Profitabilitas. Denpasar: Universitas Udayana.

Sartono, A. 2010. Manajemen Keuangan: Teori dan Aplikasi, Edisi 4. Yogyakarta: BPFE.

Serenia, S dan S. E. Hatane. 2015. Pengaruh Kegiatan Marketing terhadap Profitabilitas dan Nilai Perusahaan Properti dan Real Estate di Bursa Efek Indonesia. Business Accounting Review, Vol. 3. Surabaya: Universitas Kristen Petra.
Sitepu, D dan Linda. 2013. Analisa Faktor-Faktor yang Mempengaruhi Price Earning Ratio Perusahaan Manufaktur di Bursa Efek Indonesia. Medan: STIE Mikroskil.

Sobel, M. E. 1982. Asymptotic Confidence Interval for Indirect Effect in Structural Equation Model, Sociological Methodology. John Wiley and Sons.

Supriyadi A. 2015. Pengaruh Current Ratio, Debt to Equity Ratio, Inventory Turn Over, Return on Asset, dan Return on Equity terhadap Price Earning Ratio pada Perusahaan Manufaktur di Bidang Otomotif dan Komponen yang Terdaftar di Bursa Efek Indonesia periode 2009 - 2013. Tanjungpinang: Universitas Maritim Raja Ali Haji.

Wijaya, L. V dan L. T. Tjun. 2017. Pengaruh Cash Turn Over, Receivable Turn Over, dan Inventory Turn Over terhadap Return on Asset pada Perusahaan Makanan dan Minuman yang Terdaftar di Bursa Efek Indonesia 2013 - 2015. Bandung: Universitas Kristen Maranatha.

Yans, S. 2012. Pengaruh Intellectual Capital terhadap Kinerja Perusahaan. Bandar Lampung: Program Studi Akuntansi Universitas Lampung.

Zulfiani, I. 2016. Pengaruh Intellectual Capital terhadap Profitabilitas dan Nilai Pasar pada Perusahaan yang Tercatat di Jakarta Islamic Index Tahun 2012 - 2014. Yogyakarta: Program Studi Keuangan Syariah Universitas Islam Negeri Sunan Kalijaga.

Zurnali, C. 2010. Learning Organization, Competency, Organizational Commitment, and Customer Orientation : Knowledge Worker Kerangka Riset Manajemen Sumber Daya Manusia Masa Depan. Bandung: Unpad Press.

https://www.idx.co.id/ 